\title{
Perspective of Historical and Contemporary on Betawi Tribe's Drink Selendang Mayang
}

\author{
Firman Syah $^{1}$, Resista Vikaliana ${ }^{2}$ \\ $\left\{\right.$ firman tegal@yahoo.com 1 , resistav31@gmail.com $\left.{ }^{2}\right\}$ \\ Institut Ilmu Sosial dan Manajemen Stiami, Jakarta, Indonesia ${ }^{1,2}$
}

\begin{abstract}
This study aims to examine the Selendang Mayang Beverage from a historical and contemporary perspective. A qualitative approach was conducted to do this research. The result of this research is the standard recipe of Selendang Mayang Drink than can be used as a guide for culinary preservation, especially traditional Betawi cuisine. Beside it, this research showed about historical perspective of Selendang Mayang Drink (culinary culture value, meaning and function, culinary heritage, etc) and also Contemporer perspective.
\end{abstract}

Keywords: historical, drink Selendang Mayang, Betawi.

\section{Introduction}

Each tribe has a unique culture that is characteristic to be studied and preserved. One of the distinctive features is the typical culinary of the tribe [1]. The Betawi tribe has a long process of being able to always exist [2]. The Betawi tribe has continued to develop from time to time, with cultural characteristics that are increasingly easy to distinguish from other ethnic groups [3]. For this reason, Betawi culture can become an unforgettable legacy by all levels of society in Indonesia, especially those in Jakarta.

One of the Betawi ethnic drinks is Selendang Mayang. Currently, its existence has begun to become extinct. Few people know the origin and even the way it is made and served. In fact, usually only a few of them transmit to future generations with family ties. This means that all activities related to taste are only known by a handful of parties who already know their parents.

This Selendang Mayang Drink has been gaining popularity since the 1940s. Even though it is classified as difficult to find, when stopping at the Kota Tua area and Situ Babakan there are still many who sell this Betawi specialty. It is difficult to find this Selendang Mayang Drink because some people in Betawi themselves still consider it an ancient drink.

In the Betawi Tribe tradition, Selendang Mayang Drink is usually served at weddings, as a menu for breaking the fast or a celebration event with Betawi cultural nuances. It is believed by the Betawi tribe to eat the Selendang Mayang drink to symbolize warmth and joy. Besides being refreshing, this drink can reduce hunger because it is made with rice flour as the base ingredient.

As an intangible legacy, not only culinary delights but also those in the form of expressions and considered endangered. Therefore, as one of the categories of intangible inheritance, it must be the result of a practice that is improved from time to time [4]. This is a form of positive motivation so that no extinctions occur in intangible cultural heritage. This 
includes the arts, dance and theater. Betawi culture is very close and thick with the presence of contributions from other ethnicities, including Chinese, European and Arab [5]. So, for culinary purposes, a complete laboratory is needed to study all legalized menus.

The Betawi region is divided into three, namely North Betawi, Central Betawi, and South Betawi. The culinary study of Selendang Mayang Drink is in the middle/ city. Culinary wealth as an intangible cultural heritage is another illustration of natural [5]. In essence, if you are going to cook there are several activities that must be done and procedures so that they have different characteristics from other regions [6], [7]. This means that culinary delights cannot be separated from the human mind because there are values that are transmitted in social life.

Betawi culture is not yesterday afternoon's culture, the diversity and uniqueness of the culture proves that the Betawi people have a high level of life. Since the end of the last century and especially after independence (1945), Jakarta was flooded with immigrants from all over Indonesia so that the Betawi people - in whatever sense - lived as a minority. In 1961, the Betawi "tribe" covered approximately $22.9 \%$ of Jakarta's 2.9 million population at that time. They are increasingly being pushed to the outskirts of Jakarta, and are even busy being evicted and driven out of Jakarta. Although in fact, the Betawi 'tribe' has never been evicted or evicted from Jakarta. It is because the assimilation process of the various tribes in Indonesia has continued until now and it was through this long process that the Betawi "tribe" was present in the archipelago. With the cultural wealth possessed by the Betawi people, it is necessary to preserve this culture, given the nature of the people who do not care about their own existence [3].

Based on this, this study aims to examine the Selendang Mayang Beverage from a historical and contemporary perspective. This research is considered important to do, because the Selendang Mayang Drink has advantages and uniqueness, so that it can become an intangible cultural heritage of Betawi that is recognized nationally and even internationally [6].

\section{Method}

This research approach is a qualitative approach [8]. The data collection methods used include interviews, Focus Group Discussion / FGD with the DKI Jakarta Province Culture and Tourism Office. The key informants in this research were Anisa Sitawati and Cucu Sulaicha. Other informants were Suzen HR Tobing, Yahya Andi Saputra and Heryus Saputra. In addition, sellers of Selendang Mayang Drinks. From the data obtained, the following steps are taken:

1. Preparation of Standard Recipes

2. Presentation

3. Culinary Distribution Area

4. Culinary Cultural Value

Then, data analysis was carried out with the stages of data reduction, presenting data, and verification or drawing temporary conclusions [9].

\section{Result and Discussions}

\subsection{Drafting Standard Recipe}


The recipe for this typical Betawi drink is made from the basic ingredients of rice flour and hunkue (flour made from beans). Selendang mayang can also be identified as a starchcoated cake. The red, green, and white colors make the scarf look even more attractive. The cake dough is made from starch or palm sugar, sugar, water and food coloring, also put the pandan leaves.

In the process of making, the water is boiled until it boils, then add the pandan leaves, salt, and sugar until dissolved, or you can also add milk for flavor. Then enter the rice flour and stir quickly until well blended and evenly distributed. After cooking, pour it into the pan and add food coloring. Then spread the food coloring on the dough until blended, then cool until hardened.

To serve it, after the dough in the pan hardens, then cut it into thin strips like a layer cake just before the drink is served. Uniquely, thin bamboo is used to cut this cake. Then the cake is mixed with running brown sugar syrup and ice cubes, then poured with coconut milk sauce. It tastes sweet with a savory tinge from the use of coconut milk. Not to forget the Selendang Mayang is also usually spiked with fresh syrup water and ice cubes when eating it. Especially if eaten during the day. There are also some who serve Selendang Mayang using pieces of jackfruit to add flavor and aroma to the drink.

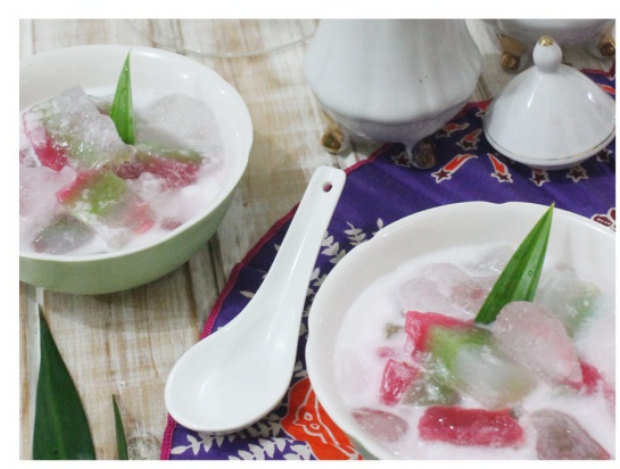

\section{Selendang Mayang}

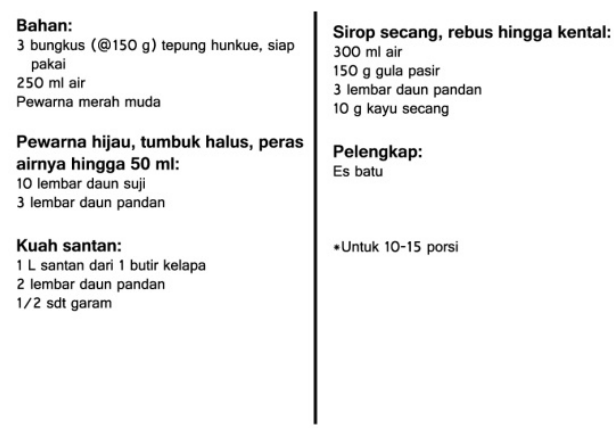

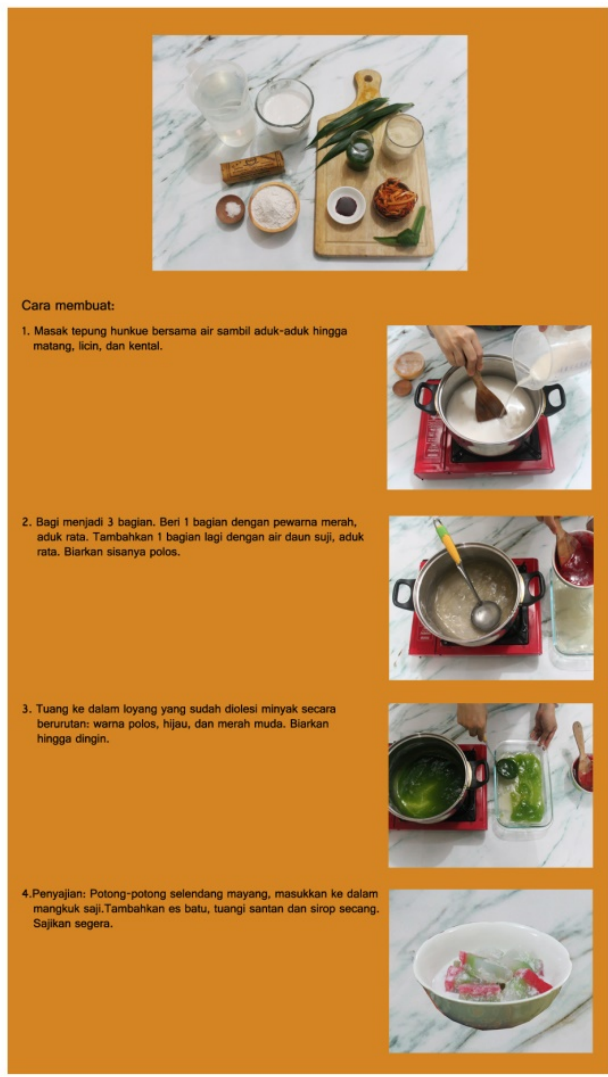

Figure 1 Recipe of Selendang Mayang Drink

\subsection{Serving}


The form of Selendang Mayang in culinary presentation is unique because it is similar to a layer cake. The name selendang mayang itself appears because of the form of these snacks. Where, 'Selendang or Shawl' comes from food colors that are green, white, and red like a dancer's scarf. Meanwhile, the word 'Mayang' means chewy and sweet. Besides shawl, this snack is similar to a layer cake at a glance. However, in terms of texture the two are very different. These colorful little pieces are more chewy and soft on the tongue.

In the past, the Selendang Mayang was sold in a simple form, namely still using the cart that went around in the villages. If there are buyers, some of the traders keep using small bowls, and the rest turn to plastic cups to serve Selendang Mayang. It's just that, nowadays, pikul model traders are rarely found anymore, except at entertainment events and from the government.

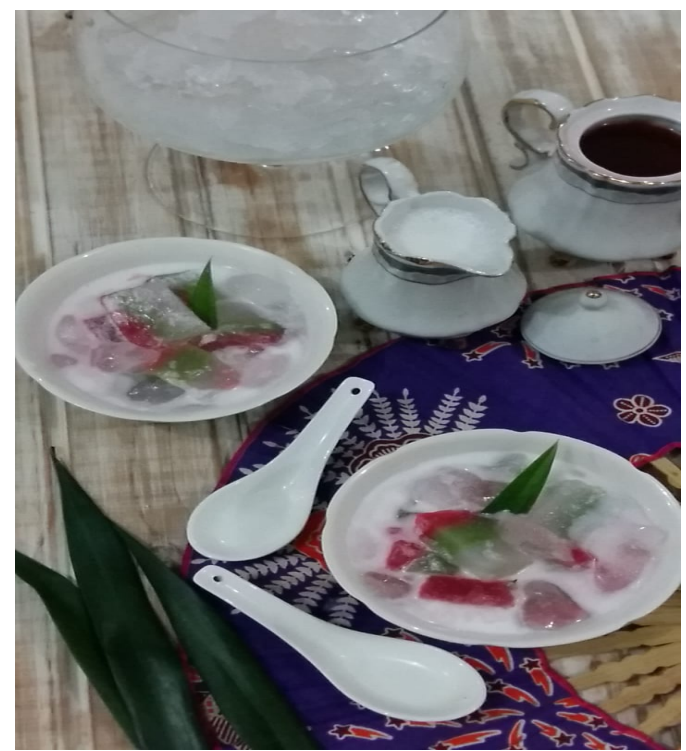

Figure 2 Selendang Mayang Drink

\subsection{Culinary Distribution Area}

Selendang Mayang drink sellers are usually found in the city area (Glodok). Also at Eat \& Eat Restaurant which is located in one of the shopping centers in the Kelapa Gading area. Including in the ragunan area and around Kemayoran. However, however the spread of the Selendang Mayang Drink area cannot be limited by the administrative area alone. Because if it is called the Betawi tribe, when there are Betawi people, you will find Betawi specialties. Apart from Kota Tua and Setu Babakan, which are still in the category of DKI Jakarta Province, Selendang Mayang Drink can also be found in the corner of Tangerang, for example the Cikokol area, Tangerang City. Until now, there are still Selendang Mayang Drink sellers who are in the sixth generation.

\subsection{Culinary Culture Value Philosophical}

There is a folk tale from Betawi which is still legendary. The name Selendang Mayang, for example, comes from a beautiful daughter named Mayangsari. This life happened in the 
Jampang era. Mayangsari's hair flows down like a beautiful scarf so it really has a beautiful aesthetic.

So, as an area that is interconnected both vertically and horizontally, there is the concept of a triangle, namely the micro cosmos and macro cosmos. This symbolizes obedience to GodAllah and is proven when the earth's alms which consist of a variety of typical Betawi culinary delights and cakes clearly have their own codes. This then becomes one of the Betawi culinary advantages that need to be preserved and preserved so that it does not become extinct from time to time. Apart from being widely known by people outside DKI Jakarta Province.

Meaning and Function (Usefulness)

There are several Betawi culinary categories that are already rare and are intended for culinary preservation. These include Sate Asem, Sengkulun, Sayur Babanci, and Porridge Ase [3]. There are also those in the category of potential for the development of typical Betawi souvenirs as souvenirs from tourists who come to DKI Jakarta Province, especially Betawi Village, namely Ginger Coffee and Coconut Roots. Finally, the culinary delights in the presentation are devoted to Betawi specialties with the aim of being one of the Betawi culinary tours. Among them are Pindang Bandeng, Sate Pentul, Laksa Betawi, and Selendang Mayang.

Where, the purpose of the appointment of Betawi culinary specialties in this case is Selendang Mayang is to raise the creativity and economic generator of local residents who indeed oblige to serve Betawi culinary. Especially for hotels and restaurants in DKI Jakarta Province, then Betawi specialties become superior. One way is by making stands in strategic locations to introduce and preserve them for the wider community. Exploring intangible cultural heritage today is indeed a lot of challenges and is the government's obligation.

\section{Culinary Heritage/ Maestro/ Successor}

Intangible cultural heritage such as this typical Betawi cuisine cannot be separated from the ingredients in the vicinity of DKI Jakarta Province. Then coupled with the creativity of the local community in making these culinary specialties were born. Where the spices or basic ingredients from one culinary to another have differences.

Is it true that the meaning of the Selendang Mayang Drink is made from the basic material of sago? In Betawi, there is also a lot like cassava flour but also imports. This means more awung flour or sugar palm, for the DKI Jakarta Province, especially along the Ciliwung River from the direction of Bogor, as the birthplace of the Betawi people and along these locations there are palm trees. In essence, human culture and civilization would not exist if there was no food. Because after all, eating and drinking has become a necessity for the community. This is what distinguishes culinary from outside Betawi with different names and ingredients.

\section{Conclusion}

The result of this research is the standard recipe of Selendang Mayang Drink than can be used as a guide for culinary preservation, especially traditional Betawi cuisine. Beside it, this research showed about historical perspective of Selendang Mayang Drink (culinary culture value, meaning and function, culinary heritage, etc) and also Contemporer perspective. 


\section{References}

[1] T. Sengel, A. Karagoz, G. Cetin, F. I. Dincer, S. M. Ertugral, and M. Balık, "Tourists' Approach to Local Food," Procedia - Soc. Behav. Sci., vol. 195, no. 2013, pp. 429437, 2015, doi: 10.1016/j.sbspro.2015.06.485.

[2] H. Ting, S. Rebecca, and A. Nastassia, "Consumption intention toward ethnic food : determinants of Dayak food choice by Malaysians," J. Ethn. Foods, vol. 4, no. 1, pp. 21-27, 2017, doi: 10.1016/j.jef.2017.02.005.

[3] M. Purbasari, "INDAHNYA BETAWI," Humaniora, no. 9, pp. 1-10, 2010, doi: https://doi.org/10.21512/humaniora.v1i1.2142.

[4] A. Batu, "Konya ( Turkey ) gastronomy culture extending to Seljuk Empire," J. Ethn. Foods, vol. 5, no. 3, pp. 184-193, 2018, doi: 10.1016/j.jef.2018.07.005.

[5] S. Oktay, "The gastronomic cultures ' impact on the African cuisine lu," vol. 5, pp. 140-146, 2018, doi: 10.1016/j.jef.2018.02.005.

[6] C. Y. Ng and S. A. Karim, "Historical and contemporary perspectives of the Nyonya food culture in Malaysia," J. Ethn. Foods, vol. 3, no. 2, pp. 93-106, 2016, doi: 10.1016/j.jef.2016.05.004.

[7] A. Batu and H. S. Batu, "Historical background of Turkish gastronomy from ancient times until today," J. Ethn. Foods, vol. 5, no. 2, pp. 76-82, 2018, doi: 10.1016/j.jef.2018.05.002.

[8] J. W. Creswell, Special issue: Authenticity, typicality, traceability and intrinsic quality offood products, vol. 60. Elsevier B.V., 2014.

[9] M. Dixon-Woods, S. Agarwal, D. Jones, B. Young, and A. Sutton, "Synthesising qualitative and quantitative evidence: A review of possible methods," J. Heal. Serv. Res. Policy, vol. 10, no. 1, pp. 45-53, 2005, doi: 10.1258/1355819052801804. 